\title{
SOIL CHANGES AND YIELD OF MAIZE FERTILIZED WITH SWINE WASTEWATER ${ }^{1}$
}

\author{
CARLOS JOSÉ GONÇALVES DE SOUZA LIMA ${ }^{2 *}$, LAÉRCIO DA SILVA PEREIRA ${ }^{3}$, THEULDES OLDENRIQUE \\ DA SILVA SANTOS ${ }^{4}$, SAMIA NATACIA PINTO ${ }^{4}$, ARTENISA CERQUEIRA RODRIGUES ${ }^{2}$, LUÍS ALFREDO \\ PINHEIRO LEAL NUNES ${ }^{2}$
}

\begin{abstract}
Swine wastewater can be used as a biofertilizer and promote significant improvements in soil physical-chemical attributes and yield. The objective of this study was to evaluate the effects of swine wastewater application on soil and maize yield. The experiment was conducted at the Agricultural Sciences Center of the Federal University of Piauí, in Teresina, Piauí, Brazil, from August to November 2015. The experimental design used completely randomized blocks in split-plot scheme, with five doses of swine wastewater $\left(0,25,50,75\right.$ and $\left.100 \mathrm{~m}^{3} \mathrm{ha}^{-1}\right)$ in the plots and two soil depths $(0.20$ and $0.40 \mathrm{~m})$ in the subplots, with four replications. Exchangeable contents of calcium, magnesium, phosphorus, potassium and sodium, electrical conductivity, $\mathrm{pH}$, sum of bases, base saturation, potential acidity and cation exchange capacity, and crop yield were evaluated. Results showed calcium, magnesium, sum of bases and cation exchange capacity increased with elevated levels of swine wastewater. Potassium and sodium contents however decreased with doses of 51.58 and $52.28 \mathrm{~m}^{3} \mathrm{ha}^{-1}$, respectively. Except for potassium and potential acidity, variables showed higher values at the $0-0.20 \mathrm{~m}$ depth.
\end{abstract}

Keywords: Organic waste. Soil attributes. Zea mays.

\section{ALTERAÇÕES NO SOLO E PRODUTIVIDADE DE MILHO-VERDE ADUBADO COM ÁGUA RESIDUÁRIA DA SUINOCULTURA}

RESUMO - A água residuária da suinocultura pode ser usada como biofertilizante e promover melhorias significativas nos atributos físico-químicos do solo e na produtividade. Objetivou-se avaliar os efeitos da aplicação da água residuária da suinocultura no solo e na produtividade do milho-verde. O experimento foi conduzido no Centro de Ciências Agrárias da Universidade Federal do Piauí, em Teresina, Piauí, no período de agosto a novembro de 2015. O delineamento experimental adotado foi em blocos casualizados em esquema de parcela subdividida, com 4 repetições, sendo os tratamentos constituídos por cinco doses de água residuária da suinocultura $\left(0,25,50,75,100 \mathrm{~m}^{3} \mathrm{ha}^{-1}\right)$ nas parcelas e duas profundidades do solo $(0,20$ e $0,40 \mathrm{~m})$ nas subparcelas. Foram avaliados os teores trocáveis de cálcio, magnésio, fósforo, potássio e sódio, condutividade elétrica, $\mathrm{pH}$, soma de bases, saturação por base, acidez potencial e capacidade de troca de cátions, e a produtividade da cultura. Os resultados demonstraram que os teores de cálcio, magnésio, soma de base e capacidade de troca de cátions aumentaram com a elevação dos níveis de água residuária da suinocultura, no entanto os teores de potássio e sódio reduziram a partir das doses de 51,58 e $52,28 \mathrm{~m}^{3} \mathrm{ha}^{-1}$, respectivamente. Com exceção do potássio e acidez potencial, as demais variáveis apresentaram maiores valores na profundidade de $0-0.20 \mathrm{~m}$.

Palavras-chave: Resíduo orgânico. Atributos do solo. Zea mays.

\footnotetext{
${ }^{*}$ Corresponding author

${ }^{1}$ Received for publication in $04 / 11 / 2018$; accepted in $12 / 04 / 2018$.

Paper extracted from the master dissertation of the fourth author.

${ }^{2}$ Department of Agricultural Engineering and Soil Science, Universidade Federal do Piauí, Teresina, PI, Brazil; carloslima@ufpi.edu.br ORCID: 0000-0003-0390-4323, artenisacerqueira@ufpi.edu.br - ORCID: 0000-0002-1621-4412, lalnunes@yahoo.com.br - ORCID: 00000003-1403-1556.

${ }^{3}$ Doctorate in Agronomy: irrigation and drainage, Universidade Estadual Paulista "Júlio de Mesquita Filho", Botucatu, SP, Brazil; abreu91@hotmail.com - ORCID: 0000-0001-8929-5084.

${ }^{4}$ Master in Agronomy: tropical agriculture, Universidade Federal do Piauí, Teresina, PI, Brazil; theuldes.santos@hotmail.com - ORCID: 0000-0003-2974-3783, nataciapinto@hotmail.com - ORCID: 0000-0001-8052-8179.
} 


\section{INTRODUCTION}

Swine farming has great importance in the social and economic development of Brazil. It generates jobs and income for producers, making viable small rural properties. But this activity may lead to serious environmental problems if the wastes generated are not properly managed (SMANHOTTO et al., 2010). Swine wastewater contains alkaline metals and heavy metals such as zinc and copper, which damage the environment and limit its use in agriculture.

Soil is a disperse, heterogeneous, polyphasic system with properties that enable it to break down organic wastes. Thus, organic wastes have emerged as an alternative fertilization method for agriculture and can lead to reduced production costs compared to chemical fertilizers, since due to their chemical composition biofertilizers increase the availability of nutrients to crops. Wastewater has been used in agriculture all over the world and is becoming increasingly important due to the scarcity of good quality water resources (CAOVILLA et al., 2010).

Swine wastewater provides a source of organic matter, nitrogen, phosphorus, potassium, calcium, sodium, magnesium, manganese, iron, zinc, copper and other elements. Its application in soil contributes to increased soil fertility, reduced environmental pollution, higher quality agricultural products and improved soil physical quality (MAGGI et al., 2011; CABRAL et al., 2011; DA ROS et al., 2017).

Maggi et al. (2013) evaluated the effects of swine wastewater on soil chemical attributes and observed increases in $\mathrm{P}, \mathrm{K}$ and $\mathrm{N}$ contents, with no effect on $\mathrm{pH}$ at the applied doses. Homem et al. (2014) found swine wastewater had no influence on $\mathrm{K}$ and $\mathrm{Mg}$ contents or $\mathrm{pH}$. Nevertheless, Oliveira, Pinheiro and Veiga (2014) observed that swine wastewater had little influence on soil physical and chemical attributes, but soil $\mathrm{pH}$ decreased and $\mathrm{P}$ content increased in the surface layers. Veiga et al. (2012) reported that continuous application of swine wastewater doses for nine years in a no-tillage system, with rotation of oats, maize and soybean, acidified the soil and increased $\mathrm{Al}, \mathrm{P}, \mathrm{Cu}$ and $\mathrm{Zn}$ contents at $0.20 \mathrm{~m}$ depth. The authors observed the highest $\mathrm{K}$ contents in the soil at $0.60 \mathrm{~m}$ depth, indicating leaching.

Swine wastewater application increases maize yield, as reported by Cassol et al. (2012), Moraes et al. (2014) and Alves Neto et al. (2016), who observed maximum yields of 10.05, 12.88 and 6.24 $\mathrm{Mg} \mathrm{ha}^{-1}$ with applications of $143,91.83$ and $140 \mathrm{~m}^{3}$ $\mathrm{ha}^{-1}$ of swine wastewater, respectively.

The objective of this study was to evaluate the changes in the physical-chemical attributes of an Argisol fertilized with swine wastewater (SWW) and its effects on the yield of maize ears under the edaphoclimatic conditions of Teresina, Piauí State, Brazil.

\section{MATERIAL AND METHODS}

The experiment was conducted from August to November 2015 at the Agricultural Sciences Center (CCA) of the Federal University of Piauí (UFPI) in Teresina-PI, Brazil, 05'2`35.78” S, $42^{\circ} 46^{\prime} 56.01^{\prime \prime} \mathrm{W}$, and altitude of $74 \mathrm{~m}$.

According to Köppen's classification, the climate of the region is Aw with mean annual rainfall of $1342.4 \mathrm{~mm}$ year $^{-1}$, mean air temperature of $28.1{ }^{\circ} \mathrm{C}$ and mean relative air humidity of $69.6 \%$ (BASTOS; ANDRADE JÚNIOR, 2016). The soil of the experimental area is classified as eutrophic Red Yellow Argisol, with sand and loamy sand textural classes in the $0.0-0.20$ and $0.20-0.40 \mathrm{~m}$ layers. The soil had the following chemical and physical attributes 15 days prior to the experiment (Table 1).

The experimental design used completely randomized blocks in split-plot scheme, where the plots corresponded to five doses of untreated SWW $\left(0,25,50,75,100 \mathrm{~m}^{3} \mathrm{ha}^{-1}\right)$ and the subplots to two soil sampling depths $(0-0.20$ and $0.20-0.40 \mathrm{~m})$, with four replications. The experimental plots consisted of three 3.3-m-long plant rows, with $0.30 \mathrm{~m}$ between plants and $0.80 \mathrm{~m}$ between rows. The central row was used for evaluations, disregarding 3 plants from each end and analyzing the center of each plot. 
Table 1. Chemical and physical analysis of the soil of the experimental area.

\begin{tabular}{lcc}
\hline \multicolumn{1}{c}{ Chemical attributes } & Depth $(\mathrm{m})$ \\
\cline { 2 - 3 } & $0-0.20$ & $0.20-0.40$ \\
\hline $\mathrm{pH}$ & 6.49 & 6.53 \\
Magnesium $\left(\mathrm{cmol}_{\mathrm{c}} \mathrm{dm}^{-3}\right)$ & 0.76 & 0.73 \\
Potassium $\left(\mathrm{cmol}_{\mathrm{c}} \mathrm{dm}^{-3}\right)$ & 0.24 & 0.29 \\
Phosphorus $\left(\mathrm{mg} \mathrm{dm}^{-3}\right)$ & 22.16 & 22.10 \\
Calcium $\left(\mathrm{cmol}_{\mathrm{c}} \mathrm{dm}^{-3}\right)$ & 2.27 & 2.19 \\
Sodium $\left(\mathrm{cmol}_{\mathrm{c}} \mathrm{dm}^{-3}\right)$ & 0.06 & 0.05 \\
$\mathrm{H}+\mathrm{Al}\left(\mathrm{cmol}_{\mathrm{c}} \mathrm{dm}^{-3}\right)$ & 1.02 & 1.06 \\
Organic matter $\left(\mathrm{g} \mathrm{dm}^{-3}\right)$ & 4.91 & 3.20 \\
CEC $\left(\mathrm{cmol}_{\mathrm{c}} \mathrm{dm}^{-3}\right)$ & 3.32 & 3.26 \\
Base saturation $(\%)$ & 76.22 & 75.39 \\
\hline \multicolumn{1}{c}{ Physical attributes $_{\text {Sand }\left(\mathrm{g} \mathrm{kg}^{-1}\right)}$} & & 1.56 \\
Silt $\left(\mathrm{g} \mathrm{kg}^{-1}\right)$ & 0.18 & 0.19 \\
Clay $\left(\mathrm{g} \mathrm{kg}^{-1}\right)$ & 940 & 790 \\
Bulk density $\left(\mathrm{g} \mathrm{cm}^{-3}\right)$ & 70 & 130 \\
\hline
\end{tabular}

The maize cultivar used was the commercial double-cross hybrid AG 1051, which is indicated for the green maize market, with excellent quality ears and good yield of unhusked ears. The total dose of SWW in each treatment was applied manually and prior to sowing, using graduated plastic containers, distributed in furrows opened to a $10 \mathrm{~cm}$ depth and incorporated into the soil with a hoe. The physicalchemical analysis of the wastewater used in the experiment is described in Table 2. The use of $75 \mathrm{~m}^{3}$ $\mathrm{ha}^{-1}$ of swine wastewater corresponded to applications of $153 \mathrm{~kg} \mathrm{ha}^{-1}$ of $\mathrm{N}, 85.5 \mathrm{~kg} \mathrm{ha}^{-1}$ of $\mathrm{P}_{2} \mathrm{O}_{5}, 90 \mathrm{~kg} \mathrm{ha}^{-1}$ of $\mathrm{K}_{2} \mathrm{O}, 42 \mathrm{~kg} \mathrm{ha}^{-1}$ of $\mathrm{Ca}$ and 15.8 $\mathrm{kg} \mathrm{ha}{ }^{-1}$ of $\mathrm{Mg}$. This is the closest dose to the recommended amount of fertilizer for maize based on the nitrogen, with this nutrient comprising the the highest content in the SWW and being required in the largest amounts by the crop, thus justifying the doses used.

The crop was irrigated by a conventional sprinkler system using SUPERJET sprinklers spaced by $12 \times 12 \mathrm{~m}$ with flow rate of $0.82 \mathrm{~m}^{3} \mathrm{~h}^{-1}$, service pressure of $25 \mathrm{mwc}$, height of $2 \mathrm{~m}$ and Christiansen's Uniformity Coefficient (CUC) of $86.84 \%$. The water used for irrigation had no limitations and was classified as $\mathrm{C} 1 \mathrm{~S} 1$. 
Table 2. Physical-chemical characterization of the untreated swine wastewater (SWW).

\begin{tabular}{lc}
\hline \multicolumn{2}{c}{ Physical-chemical composition } \\
\hline $\mathrm{N}\left(\mathrm{g} \mathrm{dm}^{-3}\right)$ & 2.04 \\
$\mathrm{P}_{2} \mathrm{O}_{5}\left(\mathrm{~g} \mathrm{dm}^{-3}\right)$ & 1.14 \\
$\mathrm{~K}_{2} \mathrm{O}\left(\mathrm{g} \mathrm{dm}^{-3}\right)$ & 1.20 \\
$\mathrm{Ca}\left(\mathrm{g} \mathrm{dm}^{-3}\right)$ & 0.56 \\
$\mathrm{Mg}\left(\mathrm{g} \mathrm{dm}^{-3}\right)$ & 0.21 \\
$\mathrm{~S}\left(\mathrm{~g} \mathrm{dm}^{-3}\right)$ & 0.16 \\
$\mathrm{Cu}\left(\mathrm{g} \mathrm{dm}^{-3}\right)$ & 0.01 \\
$\mathrm{Zn}\left(\mathrm{g} \mathrm{dm}^{-3}\right)$ & 0.01 \\
$\mathrm{Fe}\left(\mathrm{g} \mathrm{dm}^{-3}\right)$ & 0.05 \\
$\mathrm{Mn}\left(\mathrm{g} \mathrm{dm}^{-3}\right)$ & 0.01 \\
$\mathrm{pH}$ & 5.38 \\
$\mathrm{Density}\left(\mathrm{g} \mathrm{mL}^{-1}\right)$ & 1.02 \\
$\mathrm{Moisture}(\%)$ & 98.00 \\
Organic carbon $(\%)$ & 7.20 \\
$\mathrm{C} / \mathrm{N}$ ratio & 3.70 \\
Organic matter $(\%)$ & 1.30 \\
Electrical conductivity $\left(\mathrm{mS} \mathrm{cm}^{-1}\right)$ & 10.78 \\
\hline
\end{tabular}

Irrigation management was done via the climatic method, based on reference evapotranspiration $\left(\mathrm{ET}_{\mathrm{o}}\right)$, obtained through the Penman-Monteith method, adapted by the FAO. The crop coefficients $\left(\mathrm{K}_{\mathrm{c}}\right)$ obtained by Pereira Filho (2002) were used and the daily climatic data

corresponding to the period of crop permanence in the field (Figure 1) were collected at the automatic weather station of the National Institute of Meteorology (INMET), at the Brazilian Agricultural Research Corporation (EMBRAPA Mid-North) in the city of Teresina-PI, Brazil.

A

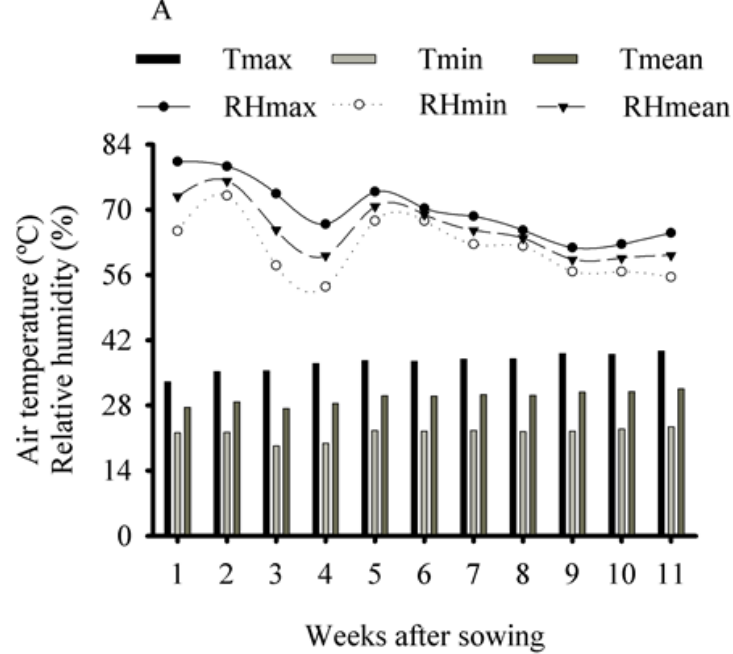

B

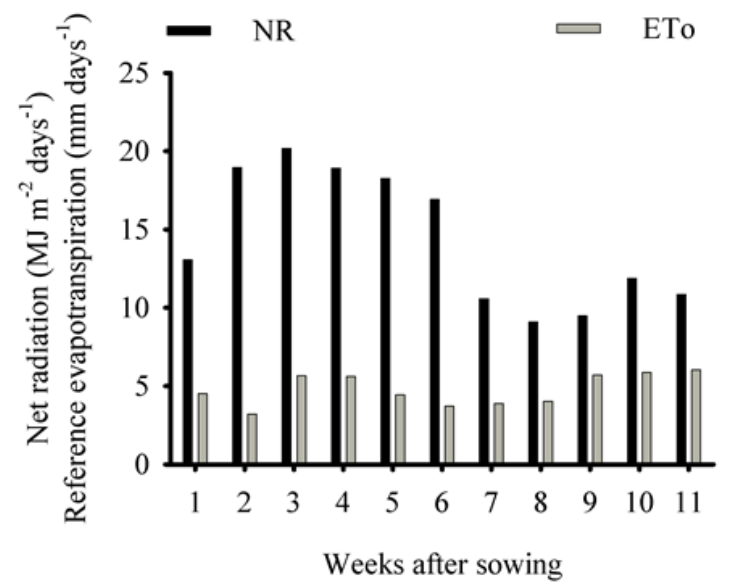

Figure 1. Climatic variables observed throughout the experimental period until 72 days after planting. Maximum (Tmax), minimum (Tmin) and mean (Tmean) temperature, maximum (RHmax), minimum (RHmin) and mean (RHmean) relative humidity $(\mathrm{A})$, net radiation $(\mathrm{Rn})$ and reference evapotranspiration $\left(\mathrm{ET}_{\mathrm{o}}\right)(\mathrm{B})$.

Weeds were controlled by manual weeding and pests and diseases were managed with applica- tions of products registered at the Ministry of Agriculture, Livestock and Food Supply (MAPA) for the 
crop and at the manufacturer's recommended doses. The harvest was carried out by hand at 72 days after planting, when the ears were well-formed and the grains were at the milky stage, with $70-80 \%$ moisture content (SILVA; PATERNIANI, 1986).

Soil was sampled 60 days after sowing by collecting 10 disturbed soil samples in each plot for physical-chemical analysis using a Dutch auger, at $0.15 \mathrm{~m}$ distance from the plant and depths of $0-0.20$ and $0.20-0.40 \mathrm{~m}$. Exchangeable contents of calcium $\left(\mathrm{Ca}^{2+}\right)$, magnesium $\left(\mathrm{Mg}^{2+}\right)$, phosphorus $(\mathrm{P})$, sodium $\left(\mathrm{Na}^{+}\right)$and potassium $\left(\mathrm{K}^{+}\right), \mathrm{pH}$, potential acidity $\left(\mathrm{H}+\mathrm{Al}^{3+}\right)$, cation exchange capacity $(\mathrm{CEC})$, sum of bases $(\mathrm{SB})$ and base saturation $(\mathrm{V} \%)$ were evaluated using the methodology of Silva et al. (2009), while soil electrical conductivity (EC) was determined according to Claessen et al. (2011). Crop yield was obtained by weighing the unhusked ears in each plot and the obtained values were converted to 1 ha.

Results were subjected to analysis of variance at 0.05 probability level. For the qualitative factor (soil depth), variables that were significant were compared by the Tukey test at 0.05 probability level. For the quantitative factor (doses), polynomial regression analysis was carried out, testing linear and quadratic models to check for treatment effects. All analyses were done using the statistical program SISVAR version 5.6.

\section{RESULTS AND DISCUSSION}

The doses of swine wastewater significantly influenced the exchangeable contents of calcium, magnesium, potassium and sodium, sum of bases and the potential and effective cation exchange capacity. Except for the potassium content and potential acidity, all parameters were influenced by the evaluated soil depths (Table 3).

Table 3. Summary of analysis of variance for exchangeable contents of Calcium (Ca), Magnesium (Mg), Potassium (K), Sodium (Na) and Phosphorus (P), Hydrogen potential $(\mathrm{pH})$, Potential acidity $(\mathrm{H}+\mathrm{Al})$, Sum of bases (SB), Electrical conductivity (EC), Potential cation exchange capacity (T), Effective cation exchange capacity $(\mathrm{t})$ and Base saturation (V) of the soil as a function of swine wastewater application and soil sampling depths.

\begin{tabular}{|c|c|c|c|c|c|c|}
\hline So $-5+$ r. & $\mathrm{Ca}$ & $\mathrm{Mg}$ & $\mathrm{K}$ & $\mathrm{Na}$ & $P$ & $\mathrm{pH}$ \\
\hline Block & $0.065^{\mathrm{ns}}$ & $0.007^{\text {ns }}$ & $0.018^{\mathrm{ns}}$ & $0.002^{*}$ & $175.315^{\mathrm{ns}}$ & $0.102^{\mathrm{ns}}$ \\
\hline Dose & $0.484^{*}$ & $0.053^{*}$ & $0.183^{* *}$ & $0.017^{* *}$ & $58.213^{\mathrm{ns}}$ & $0.192^{\mathrm{ns}}$ \\
\hline Error I & 0.127 & 0.014 & 0.013 & 0.0008 & 68.637 & 0.259 \\
\hline Depth & $1.820^{* *}$ & $0.202^{* *}$ & $0.004^{\mathrm{ns}}$ & $0.013^{* *}$ & $224.150^{* *}$ & $3.295^{* *}$ \\
\hline Dose*Depth & $0.012^{\mathrm{ns}}$ & $0.001^{\mathrm{ns}}$ & $0.008^{\mathrm{ns}}$ & 0.001 & $10.863^{\mathrm{ns}}$ & $0.038^{\mathrm{ns}}$ \\
\hline Error II & 0.120 & 0.013 & 0.004 & 0.0009 & 17.432 & 0.018 \\
\hline Overall mean & 2.260 & 0.753 & 0.259 & 0.124 & 19.372 & 7.445 \\
\hline CV I (\%) & 15.820 & 15.820 & 45.430 & 21.30 & 42.760 & 6.840 \\
\hline CV II (\%) & 15.350 & 15.360 & 26.560 & 25.31 & 21.550 & 1.840 \\
\hline Source of variation & $\mathrm{H}+\mathrm{Al}$ & SB & $\mathrm{EC}$ & CEC T & CEC $\mathrm{t}$ & $\mathrm{V}$ \\
\hline Block & $0.001^{\mathrm{ns}}$ & $0.219^{\mathrm{ns}}$ & $0.003^{\mathrm{ns}}$ & $0.203^{\mathrm{ns}}$ & $0.219^{\mathrm{ns}}$ & $6.429^{\mathrm{ns}}$ \\
\hline Dose & $0.012^{\mathrm{ns}}$ & $1.202^{*}$ & $0.005^{\mathrm{ns}}$ & $1.415^{*}$ & $1.185^{*}$ & $13.997^{\mathrm{ns}}$ \\
\hline Error I & 0.007 & 0.288 & 0.006 & 0.319 & 0.288 & 5.544 \\
\hline Depth & $0.011^{\mathrm{ns}}$ & $3.420^{* *}$ & $0.050^{* *}$ & $3.027^{* *}$ & $3.452^{* *}$ & $115.861^{* *}$ \\
\hline Dose*Depth & $0.004^{\mathrm{ns}}$ & $0.056^{\mathrm{ns}}$ & $0.0007^{\mathrm{ns}}$ & $0.063^{\mathrm{ns}}$ & $0.057^{\mathrm{ns}}$ & $1.388^{\mathrm{ns}}$ \\
\hline Error II & 0.003 & 0.203 & 0.001 & 0.232 & 0.203 & 3.120 \\
\hline Overall mean & 0.812 & 3.398 & 0.375 & 4.210 & 3.399 & 8.035 \\
\hline CV I (\%) & 10.930 & 15.790 & 20.740 & 13.430 & 15.800 & 2.930 \\
\hline CV II (\%) & 7.480 & 13.270 & 9.470 & 11.440 & 13.270 & 2.200 \\
\hline
\end{tabular}

CV-Coefficient of variation; *Significant at 0.05 probability level; **Significant at 0.01 probability level; ns- Not significant. 
The swine wastewater used in the present study as source of organic fertilizer significantly contributed to the increase in soil fertility. Therefore, it is possible to reduce the use of mineral fertilizers, which are responsible for most of the production costs in agriculture, in addition to improving environmental sustainability. The positive effect of SWW on soil fertility has also been observed by Smanhotto et al. (2010), Cabral et al. (2011), Maggi et al. (2013), Prior et al. (2015) and Da Ros et al. (2017). Nonetheless, Caovilla et al. (2010) and Condé et al. (2013) found no alterations in soil chemical characteristics with swine wastewater application and observed differences related only to the soil depths.

For the exchangeable contents of calcium $\left(\mathrm{Ca}^{2+}\right)$ and magnesium $\left(\mathrm{Mg}^{2+}\right)$ in the soil, there was an increasing linear response with the SWW application. Maximum values of 2.55 and $0.85 \mathrm{cmol}_{\mathrm{c}}$ $\mathrm{dm}^{-3}$ were obtained with an SWW application of $100 \mathrm{~m}^{3} \mathrm{ha}^{-1}$, resulting in a $23.52 \%$ gain for both variables compared to the treatment without application (Figure 2A). These results indicate the quantities of $\mathrm{Ca}^{2+}$ and $\mathrm{Mg}^{2+}$ added to the soil by the SWW are greater than those extracted from the maize crop.
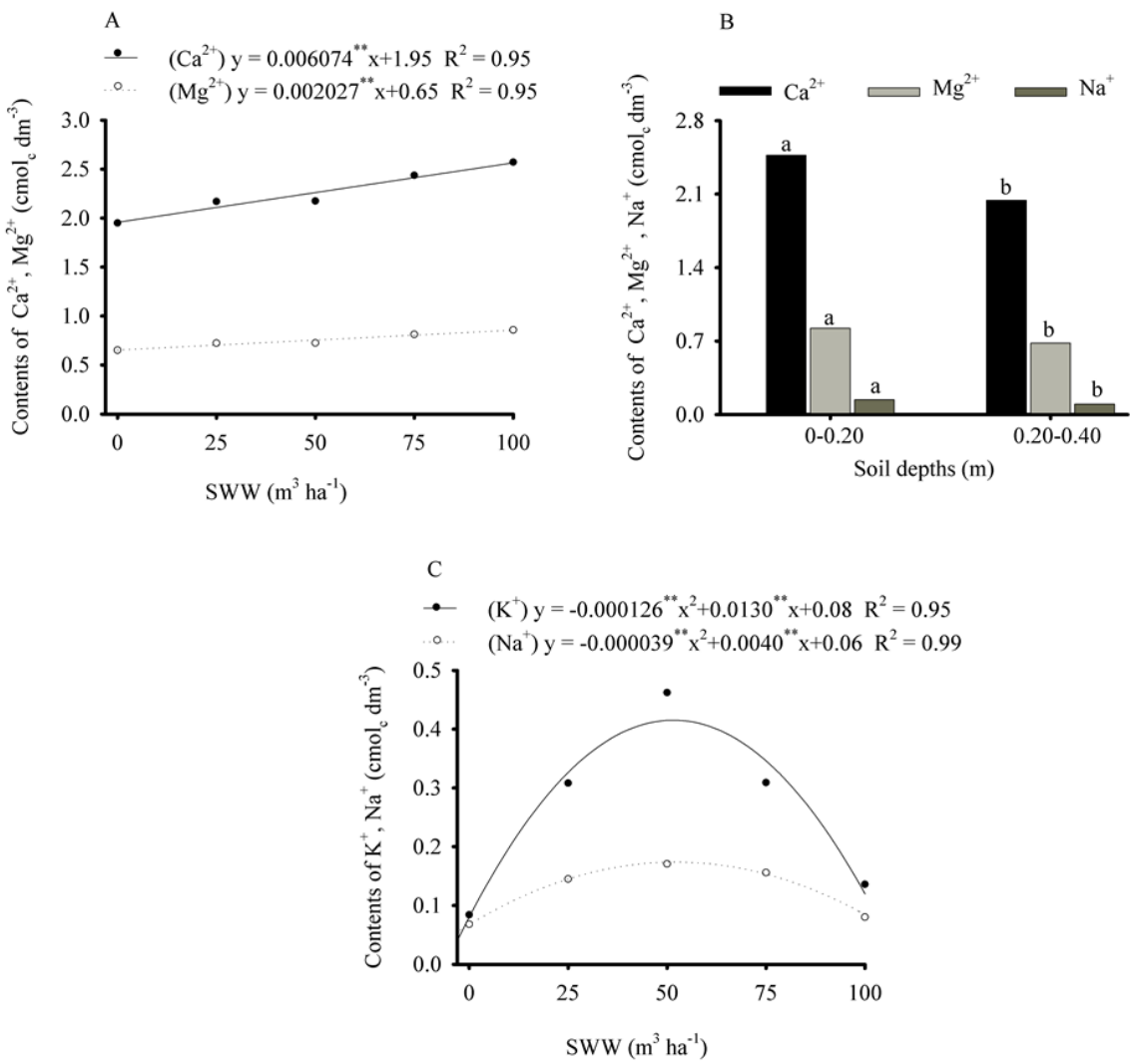

Figure 2. Regression for the exchangeable contents of calcium $\left(\mathrm{Ca}^{2+}\right)$ and magnesium $\left(\mathrm{Mg}^{2+}\right)$ in the soil as a function of doses of swine wastewater (A); test of means for $\mathrm{Ca}^{2+}, \mathrm{Mg}^{2+}$ and sodium $\left(\mathrm{Na}^{+}\right)$at the depths (B); regression for the contents of potassium $\left(\mathrm{K}^{+}\right)$and $\mathrm{Na}^{+}$in the soil as a function of SWW doses (C). Means represented by different letters at the depths differ by the Tukey test at 0.05 probability level.

Evaluating the impact of SWW on a soil classified as dystrophic Red Latosol, Cabral et al. (2011) also found a the exchangeable contents of $\mathrm{Ca}^{2+}$ and $\mathrm{Mg}^{2+}$ increased with the doses, obtaining maximum values of 0.83 and $0.34 \mathrm{cmol}_{\mathrm{c}} \mathrm{dm}^{-3}$, respectively with the application of $750 \mathrm{~m}^{3} \mathrm{ha}^{-1}$ of SWW. Da Ros et al. (2017) found $\mathrm{Ca}^{2+}$ and $\mathrm{Mg}^{2+}$ contents increased with application of SWW doses in typic aluminoferric Red Latosol. Caovilla et al.
(2010), Condé et al. (2013); Maggi et al. (2013) however found no changes in the exchangeable contents of $\mathrm{Ca}^{2+}$ and $\mathrm{Mg}^{2+}$ in the soil treated with SWW.

An analysis of the exchangeable contents of calcium $\left(\mathrm{Ca}^{2+}\right)$, magnesium $\left(\mathrm{Mg}^{2+}\right)$ and sodium $\left(\mathrm{Na}^{+}\right)$ in the soil revealed significant differences between the sampling depths. $\mathrm{Ca}^{2+}, \mathrm{Mg}^{2+}$ and $\mathrm{Na}^{+}$contents were significantly higher in the $0-0.20 \mathrm{~m}$ layer, with 
mean values of $2.47,0.82$ and $0.14 \mathrm{cmol}_{\mathrm{c}} \mathrm{dm}^{-3}$, compared to $0.20-0.40 \mathrm{~m}$, with values of $2.04,0.68$ and $0.10 \mathrm{cmol}_{\mathrm{c}} \mathrm{dm}^{-3}$, respectively (Figure $2 \mathrm{~B}$ ). These results are contrary to those obtained by Condé et al. (2013), who found no differences between SWW doses and sampling depths for the exchangeable contents of $\mathrm{Ca}^{2+}, \mathrm{Mg}^{2+}$ and $\mathrm{Na}^{+}$in the soil.

The accumulation of $\mathrm{Ca}^{2+}, \mathrm{Mg}^{2+}$ and $\mathrm{Na}^{+}$in the surface layer is explained by the increase in these nutrients in the soil due to SWW application. The high binding energy between $\mathrm{Ca}^{2+}$ and $\mathrm{Mg}^{2+}$ cationic ions and the negatively charged surfaces of soil colloids favors their permanence in the surface layer (OLIVEIRA; PINHEIRO; VEIGA, 2014; DA ROS et al., 2017). Due to the lower energy of binding to soil colloids, $\mathrm{Mg}^{2+}$ moves more easily through the soil profile compared to $\mathrm{Ca}^{2+}$ (DA ROS et al., 2017). $\mathrm{Na}^{+}$concentrations are high after wastewater applications, especially in the superficial soil layers (HOMEM et al., 2014; CONDÉ et al., 2012; 2013).

The exchangeable contents of potassium $\left(\mathrm{K}^{+}\right)$ and sodium $\left(\mathrm{Na}^{+}\right)$in the soil were influenced by the SWW doses and the data of both variables were fitted to a quadratic polynomial regression model (Figure 2C). According to this mathematical model, the maximum estimated values of 0.41 and 0.17 $\mathrm{cmol}_{\mathrm{c}} \mathrm{dm}^{-3}$ were obtained with SWW applications of 51.58 and $52.28 \mathrm{~m}^{3} \mathrm{ha}^{-1}$, respectively. A quadratic response for the exchangeable contents of $\mathrm{K}^{+}$and $\mathrm{Na}^{+}$in the soil due to the application of SWW doses has also been observed by Bernardes (2017), as well as by Cabral et al. (2011), for the exchangeable contents of $\mathrm{K}^{+}$. In contrast, Condé et al. (2013) found no significant response with the application of SWW doses for the exchangeable contents of $\mathrm{K}^{+}$and $\mathrm{Na}^{+}$in the soil.

Caovilla et al. (2010) and Prior et al. (2015) found SWW doses had no effect on the exchangeable contents of $\mathrm{K}^{+}$in the soil. Reductions in $\mathrm{K}^{+}$and $\mathrm{Na}^{+}$ from SWW doses of 51.58 and $52.28 \mathrm{~m}^{3} \mathrm{ha}^{-1}$ may be attributed to the greater extraction of these nutrients by the maize crop, which demonstrates the importance of their export to the plant dry matter.

SWW doses did not influence soil phosphorus (P) content and significant differences occurred only due to the difference in the depths evaluated (Table 3). Similar results are reported by Caovilla et al. (2010), Condé et al. (2013) and Prior et al. (2015), who found no changes in soil $\mathrm{P}$ contents with the SWW doses. In contrast, Cabral et al. (2011) observe soil P content increases linearly with SWW doses and found a maximum value of $24.36 \mathrm{mg} \mathrm{dm}^{-3}$ with the $750 \mathrm{~m}^{3} \mathrm{ha}^{-1}$ dose.

In the present study, the highest concentrations of $\mathrm{P}\left(21.74 \mathrm{mg} \mathrm{dm}^{-3}\right)$ were observed in the superficial soil layer $0-0.20 \mathrm{~m}$ (Figure $3 \mathrm{~A}$ ), demonstrating $\mathrm{P}$ soil mobility was reduced. This is due to the presence of positive organic radicals contained in the SWW, which adsorb $\mathrm{P}$, favoring its superficial accumulation (REZENDE, 2013), and to the low mobility of this element in the soil profile (CAOVILLA et al., 2010).

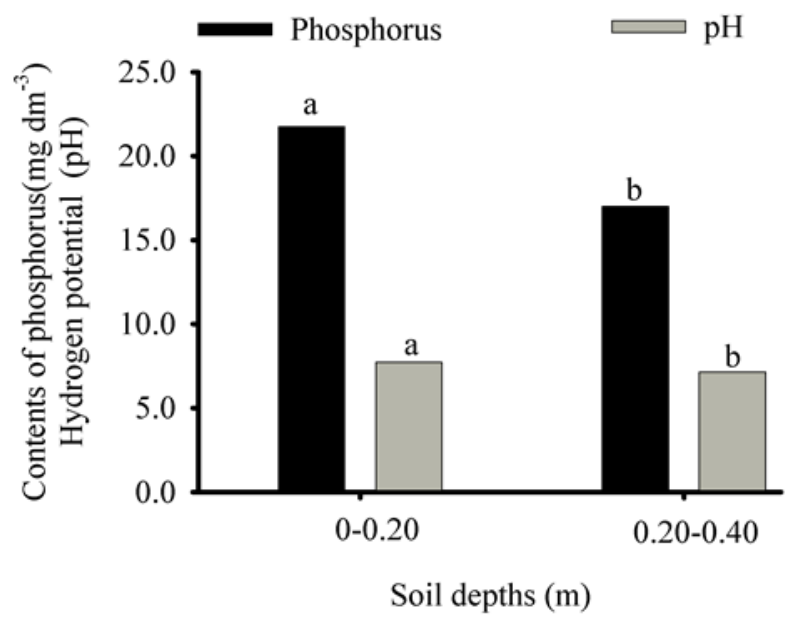

Figure 3. Means of phosphorus $(\mathrm{P})$ contents and $\mathrm{pH}$ of the soil at the evaluated depths. Means represented by different letters at the depths differ by the Tukey test at 0.05 probability level.

According to Da Ros et al. (2017), an increase of $\mathrm{P}$ content in subsurface occurs only as the adsorption sites of the adjacent layer become saturated with phosphate ions and this process only occurs in areas that receive high SWW doses and high application frequency. Caovilla et al. (2010) attributed the higher $\mathrm{P}$ contents in the $0-0.20 \mathrm{~m}$ layer to the increase in organic matter caused by SWW, with a trend toward reduced $\mathrm{P}$ content due to the reduction of organic matter as depth increases. An increase in $\mathrm{P}$ content in superficial soil layers under fertilization with SWW has also been reported by Oliveira, Pinheiro and Veiga (2014) in dystrophic Red Latosol and by Veiga et al. (2012) in a typic dystrophic Red Latosol. The mean values of $\mathrm{P}$ found at both depths in the present study are considered adequate according to Sobral et al. (2015), indicating it is not necessary to correct the $\mathrm{P}$ contents in the 
soil.

The $\mathrm{pH}$ of the soil was not affected by the SWW, but there were significant differences in the means at the evaluated soil depths at 0.01 probability level (Table 3). The response of soil pH to the SWW application is highly variable, because some studies show no changes (CABRAL et al., 2011; CASSOL et al., 2012; BRUNETTO et al., 2012; MAGGI et al., 2013; HOMEM et al., 2014; SILVA et al., 2015; BERNARDES, 2017), some show an increase (SMANHOTTO et al., 2010; LOURENZI et al., 2011; PRIOR et al., 2015; DA ROS et al., 2017) and others show a decrease (VEIGA et al., 2012; OLIVEIRA; PINHEIRO; VEIGA, 2014).

Soil $\mathrm{pH}$ decreases with depth, with mean values of 7.73 in the $0-0.20 \mathrm{~m}$ layer and 7.15 in the 0.20-0.40 m layer (Figure 3A). Compared to the beginning of the experiment however, soil $\mathrm{pH}$ increased with the SWW application at both depths (Table 1). This effect may be attributed to the reaction of carbonates present in the SWW, the decrease of $\mathrm{Al}^{3+}$ through the formation of the organometallic complex and the increase in base saturation caused by the wastes in the soil (LOURENZI et al., 2011; CASSOL et al., 2012). The lower $\mathrm{pH}$ value in the $0.20-0.40 \mathrm{~m}$ layer may have been caused by the activity of soil microbiota, due to the lower availability of organic matter in this layer.

The sum of bases (SB) of the soil represents the summation of exchangeable contents of cations $\mathrm{Ca}^{2+}, \mathrm{Mg}^{2+}, \mathrm{K}^{+}$and $\mathrm{Na}^{+}$, except $\mathrm{H}^{+}$and $\mathrm{Al}^{3+}$. Soil $\mathrm{SB}$ increased linearly due to the increase in SWW doses, with a maximum of $3.80 \mathrm{cmol}_{\mathrm{c}} \mathrm{dm}^{-3}$ obtained using $100 \mathrm{~m}^{3} \mathrm{ha}^{-1}$ of SWW (Figure 4A). Analysis of the soil depths revealed a reduction in $\mathrm{SB}$ in the 0.20 $0.40 \mathrm{~m}$ layer $\left(3.10 \mathrm{cmol}_{\mathrm{c}} \mathrm{dm}^{-3}\right)$, compared to the 0 $0.20 \mathrm{~m}$ layer $\left(3.69 \mathrm{cmol}_{\mathrm{c}} \mathrm{dm}^{-3}\right)$ (Figure 4B). These results are contrary to those found by Caovilla et al. (2010) and Condé et al. (2013), who found no changes in soil SB with the SWW doses.
A

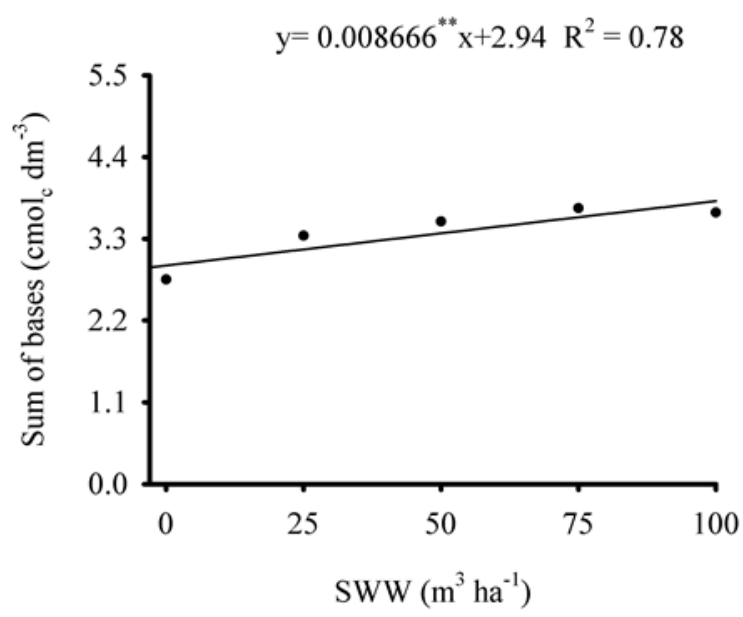

B

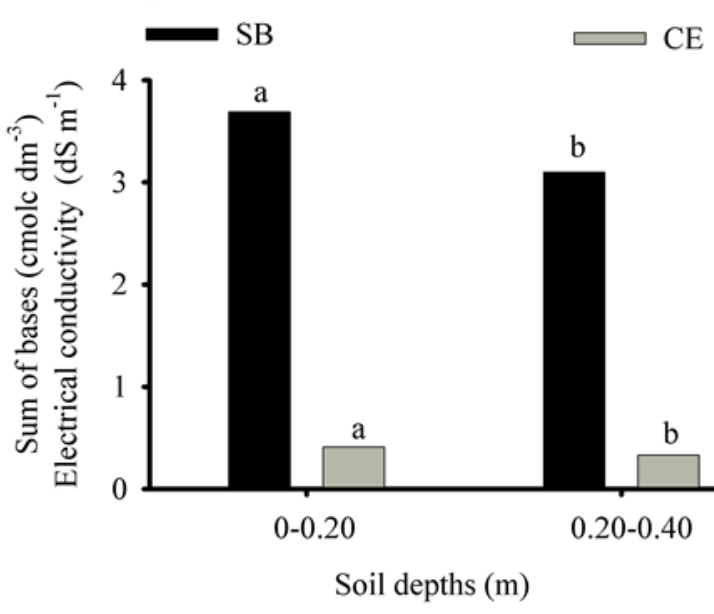

Figure 4. Regression for soil sum of bases (SB) as a function of doses of swine wastewater (A) and test of means for SB and electrical conductivity (EC) at the evaluated depths. Means represented by different letters at the depths differ by the Tukey test at 0.05 probability level.

Prior et al. (2015) and Da Ros et al. (2017) found increases in soil SB, with the highest means of 12.55 and $10.47 \mathrm{cmol}_{\mathrm{c}} \mathrm{dm}^{-3}$ at SWW doses of 112.5 $\mathrm{m}^{3} \mathrm{ha}^{-1}$ and $100 \mathrm{~m}^{3} \mathrm{ha}^{-1}$, respectively. In contrast, Homem et al. (2014) observed a decrease in SB at 138 days after successive fertigation events with SWW, attributed to the decrease in soil nutrients, which directly influence this parameter. It is probable the variations in the SB response to fertilization with SWW are related to its composition, period of evaluation, type and class of soil and local climatic conditions. The increase in SB observed in the present study reflects the supply of base cations to the soil $\left(\mathrm{Ca}^{2+}, \mathrm{Mg}^{2+}, \mathrm{K}^{+}\right.$and $\left.\mathrm{Na}^{+}\right)$by the SWW, which increased the $\mathrm{SB}$, especially in the $0-0.20 \mathrm{~m}$ layer. These elements contribute to maintaining soil $\mathrm{pH}$ under conditions favorable to the development of agricultural crops, in addition to reducing $\mathrm{Al}^{3+}$ availability.

Soil electrical conductivity (EC) did not differ between the SWW doses ( $p>0.05)$, and effect was only detected at the depths (Table 3 ). EC was higher

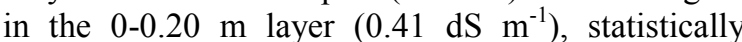
differing from the $0.20-0.40 \mathrm{~m}$ layer $\left(0.33 \mathrm{dS} \mathrm{m}^{-1}\right)$ (Figure 4B). This effect is explained by the increases in $\mathrm{K}^{+}$and $\mathrm{Na}^{+}$contents in the superficial soil layer, which generally increased with the use of SWW from 0.24 and $0.06 \mathrm{cmol}_{\mathrm{c}} \mathrm{dm}^{-3}$ (Table 1) to 0.41 and $0.14 \mathrm{cmol}_{\mathrm{c}} \mathrm{dm}^{-3}$, respectively. Similar results were found by Souza; Moreira (2010), who also observed an increase in the EC of a dystrophic Red Yellow Latosol fertigated with SWW.

Significant increases in soil EC in superficial layers with the use of wastewater have been 
observed in areas under annual crops, pastures and in forest systems (CONDÉ et al., 2012). EC is an indicator of the ion concentrations in the soil solution and low values indicate low salt concentrations in the soil profile. The EC values found in the present study are below the level considered critical for the maize crop, $1.7 \mathrm{dSm}^{-1}$ (AYERS; WESTCOT, 1999).

The potential $(\mathrm{T})$ and effective $(\mathrm{t})$ soil cation exchange capacity increased with the SWW doses, reaching maximum values of 4.68 and $3.82 \mathrm{cmol}_{\mathrm{c}} \mathrm{dm}$ -3 , respectively, at the highest dose applied (Figure 5A). By analyzing $\mathrm{T}$ and $\mathrm{t}$ at the depths studies, it was noted that the $0-0.20 \mathrm{~m}$ layer had the highest

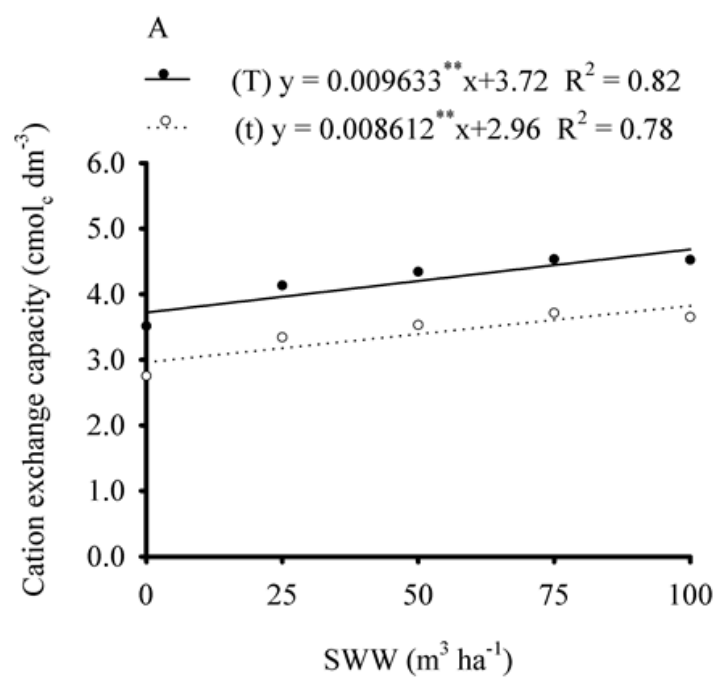

values of cation exchange capacity, 4.48 and $3.69 \mathrm{cmol}_{\mathrm{c}} \mathrm{dm}^{-3}$ (Figure 5B). These results are explained by the supply of organic matter present in the SWW (Table 2), which increases soil $\mathrm{t}$ and $\mathrm{T}$, notably in the superficial layer, reducing nutrient leaching rates. In the present study, the increase in soil $\mathrm{T}$ favored the adsorption of cationic ions contained in the SWW, such as $\mathrm{Ca}^{2+}, \mathrm{Mg}^{2+}$ and $\mathrm{Na}^{+}$ at the $0-0.20 \mathrm{~m}$ depth (Figure $2 \mathrm{~B}$ ). The soil CEC represents its capacity to retain base cations and consequently allows for evaluating their leaching potential along the soil profile (CAOVILLA et al., 2010).

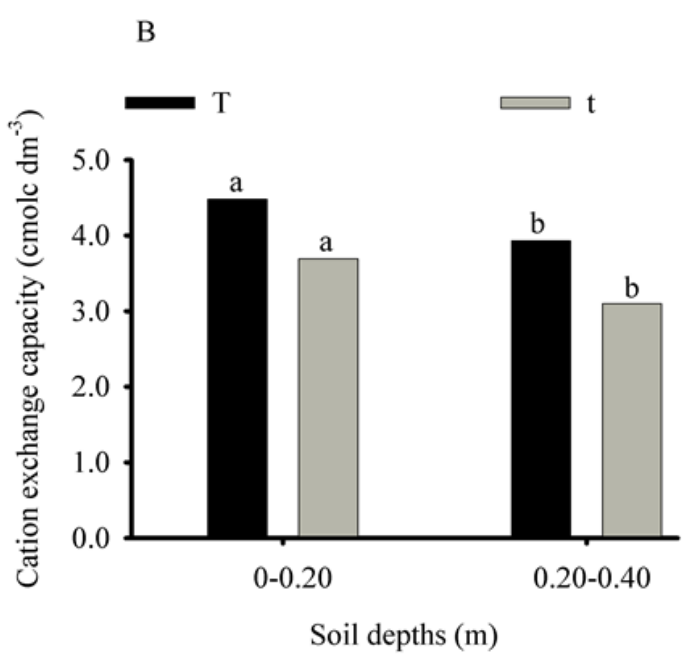

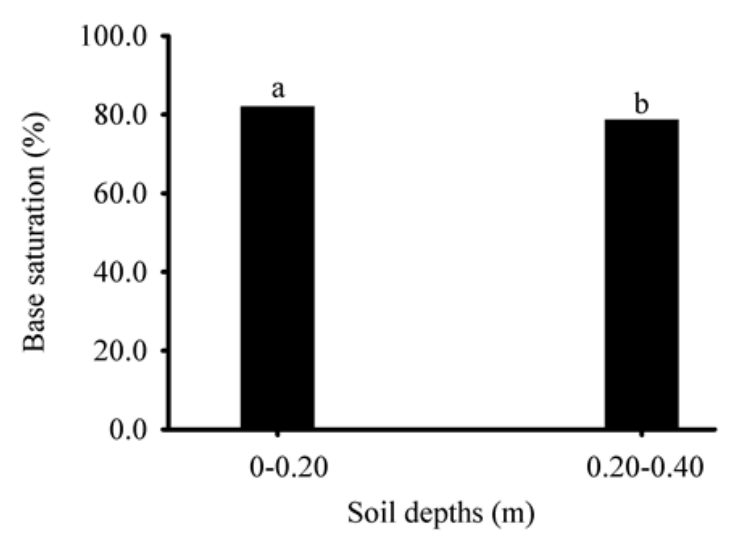

Figure 5. Regression for potential $(\mathrm{T})$ and effective $(\mathrm{t})$ soil cation exchange capacity as a function of swine wastewater doses (A); test of means for T, $t$ (B) and base saturation (C) at the evaluated depths. Means represented by different letters at the depths differ by the Tukey test at 0.05 probability level. 
Swine wastewater may contribute to an increase in soil CEC, leading to an increase in negative charges, directly through the CEC of the wastewater and indirectly in soils with dependent charges through the decrease in potential acidity $\left(\mathrm{H}+\mathrm{Al}^{3+}\right)$ (BRUNETTO et al., 2012). Additionally, in soils with sandy texture such as in the present study (Table 1), the CEC depends on the organic matter content, i.e., a reduction in organic matter contents leads to a decrease in soil CEC (HOMEM et al., 2014).

The results described here are contrary to Caovilla et al. (2010), Condé et al. (2013) and Rezende (2013), who observed no significant effect of SWW application on soil CEC. Smanhotto et al. (2010) and Da Ros et al. (2017) however found alterations in soil CEC and maximum values of 18.10 and $17.83 \mathrm{cmol}_{\mathrm{c}} \mathrm{dm}^{-3}$ at SWW doses of 300 and $100 \mathrm{~m}^{3} \mathrm{ha}^{-1}$, respectively. The differences in CEC values may be attributed to the soil classes, texture, organic matter content, waste composition and local climatic conditions.

Soil base saturation (V), which represents the proportion of exchangeable base cations relative to the potential CEC (T), was not influenced by the applied doses of SWW, but showed differences at the evaluated depths (Table 3). The lack of response to the SWW doses in soil $\mathrm{V}$ has also been reported by Caovilla et al. (2010); Condé et al. (2013); Prior et al. (2015). Comparing depths, V was significantly higher in the $0-0.20 \mathrm{~m}$ layer $(82.05 \%)$ compared to the $0.20-0.40 \mathrm{~m}$ layer $(78.64 \%$ ) (Figure $5 \mathrm{C})$. The increase in soil $\mathrm{V}$ in the $0-0.20 \mathrm{~m}$ layer results from the increase in $\mathrm{Ca}^{2+}, \mathrm{Mg}^{2+}$ and $\mathrm{Na}^{+}$(Figure 2B), which directly influence this parameter. These results are consistent with those reported by Homem et al. (2014), who also found higher soil V (64.39\%) in the $0-0.20 \mathrm{~m}$ layer at 82 days after SWW application.

Despite the lack of significant effect, the use of swine wastewater increased soil $\mathrm{V}$ at the abovementioned depths, compared to the beginning of the experiment (Table 1). According to Erthal et al. (2010), wastewaters have high concentrations of ions and organic colloids, which increase the CEC and V of the soils. The $\mathrm{V}$ values observed in the present study at both depths were above the $60-70 \%$ range required by the maize crop (RAIJ, 1991), demonstrating the potential of SWW for use as organic fertilizer.

The yield of unhusked ears was influenced by the SWW doses. The highest yield of approximately $10 \mathrm{Mg} \mathrm{ha}^{-1}$ was obtained with an SWW application of $100 \mathrm{~m}^{3} \mathrm{ha}^{-1}$, which corresponded to an expressive gain of $67.86 \%$ compared to the treatment without application (Figure 6). These results were expected because SWW application increased the levels of soil fertility, especially in the superficial layer, leading to an increase in yield.

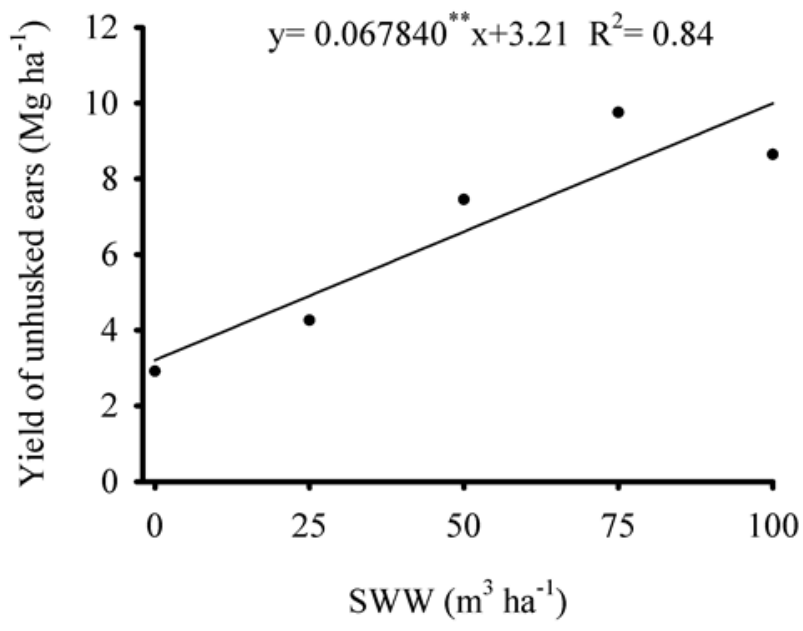

Figure 6. Regression for the yield of unhusked ears of green maize as a function of the application of swine wastewater doses.

The results found in the present study are consistent with those reported by Alves Neto et al. (2016), who also observed beneficial effects of wastewater on maize yield, with a maximum of 6.24 $\mathrm{Mg} \mathrm{ha}^{-1}$ at $140 \mathrm{~m}^{3} \mathrm{ha}^{-1}$ of SWW. Bócoli et al. (2016) however found no significant response in the yield of maize fertilized with SWW, when this waste was applied on the soil surface all at once.

\section{CONCLUSION}

The swine wastewater used as a fertilization source contributes to increasing the exchangeable contents of calcium and magnesium, sum of bases and the potential and effective cation exchange capacity of the soil, and increases maize yield, proving to be efficient when used as biofertilizer. 
The cationic ions potassium and sodium decrease with the increase in the swine wastewater doses, while the contents of calcium, magnesium, sodium and phosphorus, $\mathrm{pH}$, sum of bases, electrical conductivity, potential and effective cation exchange capacity and base saturation increased in the superficial soil layer.

\section{REFERENCES}

ALVES NETO, A. J. et al. Água residuária de suinocultura sobre a produtividade de soja e milho segunda safra: uso e viabilidade econômica. Revista Scientia Agraria Paranaensis, v. 15, n. 3, p. 350357, 2016.

AYERS, R. S.; WESTCOT, D. W. A qualidade da água na agricultura. 2.ed. Campina Grande: UFPB, 1999. 153 p. (FAO: Irrigação e Drenagem, 29).

BASTOS, E. A.; ANDRADE JÚNIOR, A. S. Boletim agrometeorológico de 2015 para o município de Teresina, Piauí. Teresina: Embrapa Meio-Norte, 2016. 38 p. (Documentos, 239).

BERNARDES, R. F. B. Água residuária de suínos em um sistema agroflorestal: atributos químicos e translocação de nutrientes no solo. 2017. 88 f. Dissertação (Mestrado em Agronomia: Área de Concentração em Solos) - Universidade Federal De Uberlândia, Minas Gerais, 2017.

BÓCOLI, M. E. et al. Soil chemical properties and maize yield under application of pig slurry biofertilizer. Revista Brasileira de Engenharia Agrícola e Ambiental, v. 20, n. 1, p. 42-48, 2016.

BRUNETTO, G. et al. Changes in soil acidity and organic carbon in a sandy typic hapludalf after medium-term pig-slurry and deep-litter application. Revista Brasileira de Ciência do Solo, v. 36, n. 5, p. 1620-1628, 2012.

CABRAL, J. R. et al. Impacto da água residuária de suinocultura no solo e na produção de capimelefante. Revista Brasileira de Engenharia Agrícola e Ambiental, v. 15, n. 8, p. 823-831, 2011.

CAOVILLA, F. A. et al. Características químicas de solo cultivado com soja e irrigado com água residuária da suinocultura. Revista Brasileira de Engenharia Agrícola e Ambiental, v. 14, n. 7, p. 692-697, 2010.

CASSOL, P. C. et al. Disponibilidade de macronutrientes e rendimento de milho em latossolo fertilizado com dejeto suíno. Revista Brasileira de Ciências do Solo, v. 36, n. 6, p. 1911-1923, 2012.
Claessen, M. E. C. et al. Manual de Métodos de Análise de Solo. 2. ed. Rio de Janeiro, RJ: Embrapa - CNPS, 2011. 212 p.

CONDÉ, M. S. et al. Impacto da fertirrigação com água residuária da suinocultura em um latossolo vermelho-amarelo. Revista Vértices, v. 15, n. 2, p. 161-178, 2013.

CONDÉ, M. S. et al. Influência da aplicação de águas residuárias de criatórios de animais no solo: atributos químicos e físicos. Revista Brasileira de Agropecuária Sustentável, v. 2, n. 1, p. 99-106, 2012.

DA ROS, C. O. et al. Disponibilidade de nutrientes e acidez do solo após aplicações sucessivas de água residuária de suinocultura. Revista Brasileira de Tecnologia Agropecuária, v. 1, n. 1, p. 35-4, 2017.

ERTHAL, V. J. T. et al. Alterações físicas e químicas de um Argissolo pela aplicação de água residuária de bovinocultura. Revista Brasileira de Engenharia Agrícola e Ambiental, v. 14, n. 5, p. 467-477, 2010

HOMEM, B. G. C. et al. Efeito do uso prolongado de água residuária da suinocultura sobre as propriedades químicas e físicas de um Latossolo Vermelho-Amarelo. Revista Científica, v. 42, n. 3, p. 299-309, 2014.

LOURENZI, C. L. et al. Soil chemical properties related to acidity under successive pig slurry application. Revista Brasileira de Ciência do Solo, v. 35, n. 5, p. 1827-1836, 2011.

MAGGI, C. F. et al. Lixiviação de nutrientes em solo cultivado com aplicação de água residuária de suinocultura. Revista Brasileira de Engenharia Agrícola e Ambiental, v. 15, n. 2, p. 170-177, 2011.

MAGGI, C. et al. Impacts of the application of swine wastewater in percolate and in soil cultivated with soybean. Engenharia Agrícola, v. 33, n. 2, p. 279 290, 2013.

MORAES, M. T. et al. Dejetos líquidos de suínos como alternativa a adubação mineral na cultura do milho. Revista Semina: Ciências Agrárias, v. 35, n. 6, p. 2945-2954, 2014.

OLIVEIRA, D. A.; PINHEIRO, A.; VEIGA, M. Effects of pig slurry application on soil physical and chemical properties and glyphosate mobility. Revista Brasileira de Ciência do Solo, v. 38, n. 5, p. 1421-1431, 2014.

PEREIRA FILHO, I. A. O cultivo de milho-verde. 1. ed. Sete lagoas, MG: Embrapa Milho e Sorgo, 
2002. $217 \mathrm{p}$.

PRIOR, M. et al. Estudo da associação de água residuária de suinocultura e adubação mineral na cultura do milho e no solo. Revista Engenharia Agrícola, v. 35, n. 4, p. 744-755, 2015.

RAIJ, B. VAN. Fertilidade do solo e adubação. 2. ed. Piracicaba, SP: Ceres, 1991. 343 p.

REZENDE, V. O. Efeito da fertirrigação com água residuária de suinocultura nos atributos químicos do solo e na produção dos capins tifton 85 e xaraés. 2013. 60 f. Dissertação (Mestrado em Agronomia: Área de Concentração em Produção Vegetal) - Universidade Federal de Viçosa, Minas Gerais, 2013.

SILVA, A. A. et al. Fertilização com dejetos suínos: Influência nas características bromatológicas da Brachiaria decumbens e alterações no solo. Revista Engenharia Agrícola, v. 35, n. 2, p. 254-265, 2015.

SILVA, F. C. Manual de análises químicas de solos, plantas e fertilizantes. 2. ed. Brasília, DF: Embrapa Informação Tecnológica, 2009. 627 p.

SILVA, P. S. L.; PATERNIANI, E. Produtividade de milho verde e de grãos de cultivares de Zea mays L. Ciência e Cultura, v. 38, n. 4, p. 707-712, 1986.

SMANHOTTO, A. et al. Cobre e zinco no material percolado e no solo com a aplicação de água residuária de suinocultura. Revista Engenharia Agrícola, v. 30, n. 2, p. 346-357, 2010.

SOBRAL, L. F. et al. Guia prático para interpretação de resultados de análises de solos. Aracaju, SE: Embrapa Tabuleiros Costeiros, 2015. 13 p. (Documentos, 206).

VEIGA, M. et al. Chemical attributes of a Hapludox soil after nine years of pig slurry application. Revista Pesquisa Agropecuária Brasileira, v. 47, n. 12, p. 1766-1773, 2012. 